\title{
Evaluation of Incidence of Hepatitis C in Health Care Workers
}

\author{
Sanjay Kumar ${ }^{1}$, Dharmendra Prasad ${ }^{2}$ \\ ${ }^{1}$ Assistant Professor, Department of Medicine, Govt. Medical College, Bettiah, ${ }^{2}$ Associate Professor, Department of Medicine, Govt. Medical College, \\ Bettiah.
}

\section{Abstract}

Background: Hepatitis C virus infection continues to be a major public health problem warranting high priority efforts for control and treatment. Aim: An observational, cross-sectional facility-based study was conducted to measure the prevalence of HCV infection and to identify risk factors associated with HCV infection among health care workers. Subjects and Methods: A total of 109 participants were selected. It conducted through stratified random sampling. For the analysis, Z-test and Fisher's exact test were used. All participants in this study were tested for HCV marker (Anti-HC). Results: The positive for Anti-HC was found to be 1.8\% (2/109), which was found among nurses and paramedics. The results showed association between Anti-HC positivity and blood transfusion, frequency of blood transfusion and exposure to sharp injuries, $\mathrm{P}$ values $(0.003,0.0001$ and 0.029$)$ respectively. Conclusion: Prevalence rate of Anti-HC was found to be low in HCWs $(1.8 \%)$. The prevalence rate was found among nurses and medical engineers. Blood transfusion, frequency of blood transfusion and exposures to sharp injuries to be risk factors with Anti-HC positivity.

Keywords: HCV marker, Dialysis Centers (Units), health care workers, riskfactors, Khartoum State, Sudan.

Corresponding Author: Dr. Dharmendra Prasad, Associate Professor, Department of Medicine, Govt. Medical College, Bettiah.

Received: September 2019

Accepted: September 2019

\section{Introduction}

Hepatitis $\mathrm{C}$ virus infection continues to be a major public health problem. WHO estimates that HCV infection has an estimated worldwide prevalence of more than 500 million cases ${ }^{[1]}$ Approximately, 170 million people worldwide are chronically infected with hepatitis $\mathrm{C}$ virus $(\mathrm{HCV}) .^{[2]}$ The health care workers (HCWs) are at risk of infection with blood borne pathogens through occupational exposure to blood and infectious body fluids. ${ }^{[3]}$ Approximately 3 million percutaneous exposures to blood borne pathogens occur annually among 35 million HCWs worldwide. These injuries are estimated to result in 16,000 hepatitis C, 66,000 hepatitis $\mathrm{B}$, and 200 to $5000 \mathrm{HIV}$ infections. Over $90 \%$ of these infections are occurring in low-income countries, and most are preventable. ${ }^{[4]}$ Low endemicity areas Include North America, Western Europe and Australia, where anti-HCV anti-bodies $<1.5 \%$. Areas with intermediate endemicity Include Mediterranean countries and Asia (Anti-HCV 1$2 \%$ ), while the highest endemicity has been detected in Africa, South- Eastern Asia and Latin America (Anti-HCV $>2 \%$ ). HCV infections are strongly associated with hepatocellular carcinoma, the prevalence of $\mathrm{HCV}$ was found to be $1.5 \%$ among the hepatocellular carcinoma patients in Sudan. ${ }^{[5]}$ Seroprevalence rate of HCV among Sudanese in range (between 2.2\% to 4.8\%).6 In Omdurman-Sudan, a cross - sectional study was conducted showed the seroprevalence of $\mathrm{HCV}$ was zero $(0.0 \%) \mathrm{HCWs} .{ }^{[7]}$
Limited information regarding to $\mathrm{HCV}$ infection among North Indian health care workers for this reason we conducted this study aims to measure the prevalence of HCV infection and to identify risk factors associated with $\mathrm{HCV}$ infection among nurses and paramedics.

\section{Subjects and Methods}

The study was conducted at at government medical college, Bettiah. The study was approved by the institutional research committee. This study was observational, cross-sectional facility based study. A total of 109 health care workers participated in the study. Nurses and paramedics in direct or indirect contact with patients or with blood or other body fluids from patients in the hospital were included in the study. The study was explained to the participating subjects, and a written consent was taken.

A pre-tested, pre-coded self administered questionnaire was used to collect socio-demographic characteristics (age, sex, education, marital status, occupation and duration of the work), past medical history (blood transfusion, frequency of blood transfusion, surgical operation, exposure to needle stick, using shared razors and tattoos).

Under sterilized condition about $(5 \mathrm{ml})$ of venous blood was taken from each participant through venepuncture using a vacutainer device (blood collection containers) (EDTA container), the samples was stored upright in an ice box (vaccine carrier)/refrigerator. Then the sera were separated 
by centrifugation at $3000 \mathrm{rpm}$ for 5 minutes and stored at 20o centigrade till testing. ELISA was used to screen AntiHC.

The data was tabulated and subjected to statistical analysis using SPSS (statistical package for social sciences) version 10. For the analysis, binomial test (Z-test) for single proportion and some nonparametric tests such as Fisher's exact test were used, Pvalue of $<0.05$ was considered statistically significant.

\section{Results}

A total of one hundred and nine HCWs were recruited to the study. Sixty nine of HCWS $(65.1 \%)$ were female and $(34.9 \%)$ were male. [Figure 1]

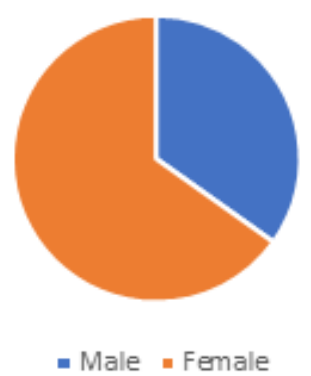

Figure 1: frequency of males and females.

The age group 21-30 years represents $63.3 \%$ of participants, flowed by the age group 31-45 years $38(34.9 \%)$ and only 2 $(1.8 \%)$ in $18-20$ years. [Figure 2]

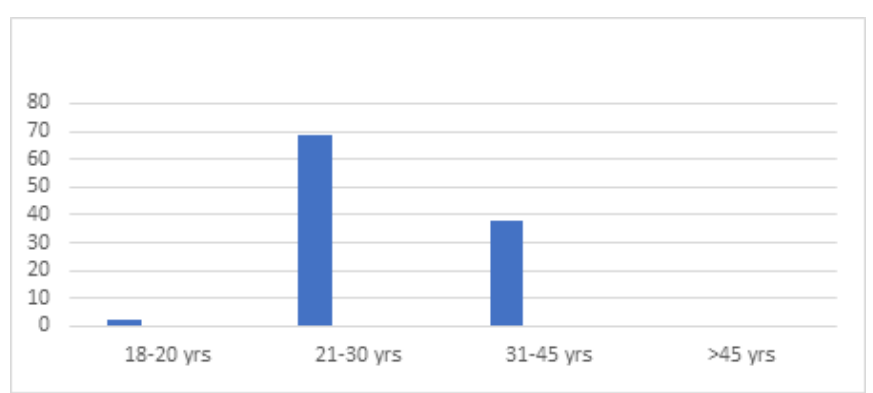

Figure 2: Number of subjects in age range.

Twenty seven of HCWs (24.8\%) were married while 82 (75.2\%) unmarried. [Figure 3]

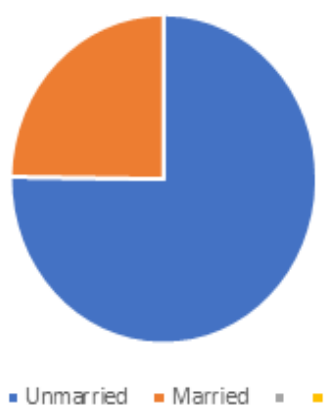

Figure 3: Married Vs Unmarried
Concerning educational level $81.7 \%$ of $\mathrm{HCW}$ s were Secondary level educated, $12.8 \%$ were graduate, $4.6 \%$ high school and $1 \%$ primary education.

Regarding the occupation $73(67 \%)$ HCWs were nurses, 11 (10.1\%) lab. Technician, $10(9.2 \%)$ dresser, $8(7.3 \%)$ ot assistant, $43.7 \%$ Para medicals, Concerning to the duration of the work $60.5 \%$ of HCWs in 1-5 years flowed by the duration $6-10$ years $15.6 \%$, less than one year $14.7 \%$ and more than ten years $9.2 \%$. [Table 1]

Table 1: Demographic characteristic of anti-HC positive subjects and healthcare workers

\begin{tabular}{|l|l|l|}
\hline Characteristic & Frequency & Anti -HC Positive \\
\hline Sex & 38 & 0 \\
\hline Male & 71 & 2 \\
\hline Female & 2 & 0 \\
\hline Age group & 69 & 2 \\
\hline $18-20$ & 38 & 0 \\
\hline $21-30$ & 0 & 0 \\
\hline $31-45$ & \multicolumn{2}{|l|}{} \\
\hline$>45$ & 27 & 0 \\
\hline Marital status & 82 & 2 \\
\hline Married & \multicolumn{2}{|l|}{} \\
\hline Unmarried & 6 & 0 \\
\hline Educational level & 89 & 2 \\
\hline High school & 14 & 0 \\
\hline Secondary & 12 & 0 \\
\hline Graduate & 73 & 1 \\
\hline Occupational category & 05 & 0 \\
\hline Dresseer & 11 & 1 \\
\hline Nurse & 08 & 0 \\
\hline Paramedical & \multicolumn{2}{|l|}{} \\
\hline Lab technician & 20 & 1 \\
\hline Ot assistant & 69 & 1 \\
\hline Duration of work & 13 & 0 \\
\hline$<1$ year & 07 & 0 \\
\hline $1-5$ year & \\
\hline $6-10$ year & \multicolumn{2}{|l|}{} \\
\hline$>10$ year &
\end{tabular}

Socio-demographic characteristics associated with Anti-HC positivity shows the socio-demographic characteristics of HCW, from table the positive cases among female $2.8 \%$ (2/71). Regarding to the age group the tow positive cases recorded in age group 15-30 years. Also the two positive cases among unmarried $2.4 \%$ (2/82). For the educational level the positive cases among secondary level $2.2 \%(2 / 89)$. Concerning to the occupation, the prevalence among lab technician and nurses $12.5 \%$ and $1.4 \%$ respectively.

\section{Discussion}

The overall prevalence of $\mathrm{HCV}$ infection was $0.18 \%$ [Table 1] and rate of prevalence females were higher. Prevalence of HCV infection was different in all age group in range 0 to $1.8 \%$. The study showed maximum prevalence of HCV infection in aged 15-30 years. Out of total positive maximum number of patients were identified in unmarried females.

Acute HCV infection is usually asymptomatic so infection remains undiagnosed, usually it diagnosed accidentally or when it becomes chronic. It is estimated that only 30-50\% of individuals infected with $\mathrm{HCV}$ are aware of their disease (Rajesh, 2012). 
Hepatitis $\mathrm{C}$ infection is found worldwide, prevalence rates are also different e.g. 5.5\% in Africa, $4.6 \%$ in the Eastern Mediterranean region, $4 \%$ in the Western Pacific region, $2 \%$ in South East Asia, $1.7 \%$ in the United States of America (USA), $1 \%$ in Europe14 and 28\% in Egypt were noted in past (Sy et al., 2006).

Risk factors for HCV transmission differ between developed and developing countries. Transmission of $\mathrm{HCV}$ was strongly associated with intravenous and percutaneous drug users (IDUs).Studies from the developed countries also reveals that most of the new $\mathrm{HCV}$ infection assciated with injection drug use (Wasley et al., 2000).

In the developing countries, unsafe therapeutic injections and transfusions are likely to be the major modes of transmission, especially in countries where age-specific seroprevalence rates suggest ongoing increased risk of $\mathrm{HCV}$ infection (Shepard et al., 2005).

The seroprevalence of HCV among general population of India has been reported between 0.22-1.8 per cent (Gowri et al., 2012; Jaiswal et al., 1996).

In our study overall prevalence of HCV infection is $0.18 \%$ which is similar to study done by Gowri et al., $(0.22 \%)$, lower seropositivity was reported from Madurai, while study done by Preeti Mindolii et al., (2.6\%) and Mishra et al., (1.57\%) Showed higher prevalence as compare to our study. Differences in prevalence rates may be due differences in health resources and educational levels awareness of the disease in different regions. The prevalence of $\mathrm{HCV}$ in both genders is controversial. While some studies showed higher $\mathrm{HCV}$ incidence among men, other population based surveys showed similar rates in both sexes. In this study prevalence were higher for females. The present study revealed significant trend of HCV seropositivity with relation to age, highest prevalence was noted in adults. Study done by Preeti Mindolli et al., also showed contrast result, in present study highest prevalence was noted in older age group, may be the reason that late diagnosis in older age group due unavailability of facilities at that time. After older age group significant numbers of $\mathrm{HCV}$ positive patients were found in younger age group (20-29 yr). Intravenous drug abuse is very common in this age group so it can be the first reason of $\mathrm{HCV}$ transmission and early diagnosis due to improvement in health care facilities as well as patients awareness of diseases can be the other reason.

\section{Conclusion}

$\mathrm{HCV}$ would be responsible for emerging infection in India. In order to prevent transmission of infection, educational program and screening to target group as well as illiterate people in collaboration with health care provider are require.

\section{References}

1. Atreyi Chakraborty et al. 2015. A Retrospective Study on the Seroprevalence of Hepatitis C Infection in a Tertiary Care Hospital in Kolkata, India. Int. J. Curr. Microbiol. App. Sci., 4(3): 115-123.

2. Chandra, M., Khaja, M.N., Farees, N., Poduri, C.D., Hussain, M.M., Aejaz, H., et al. 2003. Prevalence risk factors and genotype distribution of $\mathrm{HCV}$ and $\mathrm{HBV}$ infection in the tribal population: A community based study in South India. Trop. Gastroenterol., 24: 193-94.
3. Chandrasekaran, S., Palaniappan, N., Krishnan, V., Mohan, G., Chandrasekaran, N. 2000. Relative prevalence of hepatitis B viral markers and hepatitis $\mathrm{C}$ virus antibodies (anti HCV) in Madurai, south India. Indian J. Med. Sci., 54: 270-73.

4. Chen, S.L., Morgan, T.R. 2006. The natural history of hepatitis C virus (HCV) infection. Int. J. Med. Sci., 47-52.

5. Farag, M.M., Sofy, A.R., Mousa, A.A., Ahmed, M.A., Alganzory, M.R. Molecular Assay and Genotyping of Hepatitis C Virus among Infected Egyptian and Saudi Arabian Patients. Virology (Auckl)., 6:110.

6. Gao, X., Cui, Q., Shi, X., Su, J., Peng, Z., Chen, X., et al. 2011. Prevalence and trend of hepatitis $\mathrm{C}$ virus infection among blood donors in Chinese mainland: a systematic review and meta-analysis. BMC Infect Dis., 11: 88.

7. Gowri, V., C. Chandraleka, R. Vanaja. 2012. The Current Seroprevalence of Hepatitis C Virus in a Tertiary Care Centre in Vellore, Tamil Nadu. Indian J. Community Med., Volume: 37 Issue: 2, 37.

8. Gowri, V., Chandraleka, C., Vanaja, R. 2012. The current seroprevalence of hepatitis $\mathrm{C}$ virus in a tertiary care centre in Vellore, Tamil Nadu. Indian J. Community Med., 37: 137.

9. Jaiswal, S.P., Chitnis, D.S., Naik, G., Artwani, K.K., Pandit, C.S., Salgia, P., et al., Prevalence of anti-HCV antibodies in central India. Indian J. Med. Res., 104: 177-81.

10. Khaja, M.N., Madhavi, C., Thippavazzula, R., Nafeesa, F., Habib AM, Habibullah CM, et al. 2006. High prevalence of hepatitis C virus infection and genotype distribution among general population, blood donors and risk groups. Infect. Genet. Evol., 6: 198-204.

11. Mishra, S., Chayani, N., Sarangi, G., Mallick, B., Pati, S.B. 2002. Seroprevalence of anti HCV antibody in and around Cuttack, Orissa. Indian J. Med. Microbiol., 20: 401.

12. Mukhopadhyaya, A. 2008. Hepatitis C in India. J. Biosci., 33: 465-473.

13. Parisa Ebrahimzadeh, Mohammadreza Haghshena and Farhang Babamahmoodi. The Prevalence of Hepatitis C Virus Genotypes in Mazandaran Province, Iran Jundishapur J. Microbiology.

14. Parveen Malhotra, Vani Malhotra, Naveen Malhotra, Ishita Singh, Ajay Chugh and Abhishek Chaturvedi. Epidemiological Profile of Hepatitis C Patients at India's New Hub -Haryana Adv. Res. Gastroentero Hepatol., 1(1): ARGH.MS.ID.555554.

15. Ponamgi, S.P., Rahamathulla, S., Kumar, Y.N., Chandra, M., Lakshmi, N., Habibullah, C.M., et al. 2009. Prevalence of hepatitis C virus (HCV) coinfection in HIV infected individuals in south India and characterization of HCV genotypes. Indian J. Med. Microbiol., 27: 126.

16. Preeti, B., Mindolli, Manjunath, P., Salmani. 2015. Seroprevalence of Hepatitis C Virus in a Tertiary Care Centre in Vijaypur, Karnataka, India. Int. J. Curr. Microbiol. Appl. Sci., Volume 4 Number 10: pp. 956959

17. Rajesh, N., Gacche and Sadiq K. Al-Mohani, 2012. "Seroprevalence and Risk Factors for Hepatitis C Virus Infection among General Population in Central Region of Yemen," Hepatitis Research and Treatment, vol. 2012, Article ID 689726, 4 pages, 2012.

18. Saravanan, S,. Velu, V., Kumarasamy, N., Nandakumar, S., Murugavel, K.G., Balakrishnan, P., et al. 2007. Coinfection of hepatiits B and hepatitis $\mathrm{C}$ virus in HIV infected patients in south India. World J. Gastroenterol., 13: 5015-20.

19. Shepard, C.W., L. Finelli, and M. J. Alter, 2005. "Global epidemiology of hepatitis C virus infection," The Lancet Infectious Dis., vol. 5, no. 9, pp. 558- 567 .

20. Shobokshi, O.A., F.E. Serebour, A.Z. Al Drees, A.H. Mitwalli, A. Qahtani, and L.I. Skakni. 2003. "Hepatitis C virus seroprevalence rate among Saudis," Saudi Med. J., vol. 24, supplement 2, pp. S81- S86.

21. Sy, T. and M. Mazen Jamal. 2006. "Epidemiology of hepatitis C virus (HCV) infection," Int. J. Med. Sci., vol. 3, no. 2, pp. 41-46, 2006

22. Tripathi, A.K., Khanna, M., Gupta, N., Chandra, M. 2007. Low prevalence of hepatitis B virus and hepatitis C virus coinfection in patients with human immunodeficiency virus in Northern India. J. Assoc. Physicians India, 55: 429-31.

23. Wasley, A. and M.J. Alter. 2000. "Epidemiology of hepatitis C: geographic differences and temporal trends," Seminars in Liver Disease, vol. 20, no. 1, pp. 1-16.

24. Who hepatitis C fact sheet updated July, 2016. Zidan, A., Scheuerlein, H., Schule, S., Settmacher, U., Rauchfuss, F. 2012. Epidemiological pattern of hepatitis $\mathrm{B}$ and hepatitis $\mathrm{C}$ as etiological agents for hepatocellular carcinoma in iran and worldwide. Hepat Mon., 12(10 HCC). 
Copyright: () the author(s), 2019. It is an open-access article distributed under the terms of the Creative Commons Attribution License (CC BY 4.0), which permits authors to retain ownership of the copyright for their content, and allow anyone to download, reuse, reprint, modify, distribute and/or copy the content as long as the original authors and source are cited.

How to cite this article: Kumar S, Prasad D. Evaluation of Incidence of Hepatitis C in Health Care Workers.. Acad. J Med. 2019; 2(2):99-102.

DOI: dx.doi.org/10.21276/ajm.2019.2.2.25

Source of Support: Nil, Conflict of Interest: None declared. 